\title{
Some new competitive advantages in the field of energetic paradigm shift from coal and gas towards the blue hydrogen production
}

\author{
Vlad EPURESCU \\ Bucharest University of Economic Studies, Bucharest, Romania \\ vlad.epurescu@gmail.com
}

\begin{abstract}
Achieving the 2030 and 2050 climate targets gears up several economic opportunities but also a package of threats for the EU Member States. The economic crisis caused by the COVID-19 pandemic will accelerate the energy transition, which is becoming an engine of post-coronavirus economic growth. In this landscape, new economic governance, speeding up innovation, cutting the red tape, and improving access to human and financial resources becomes essential for ensuring a sustainable and long-lasting economic development which is linked with reducing the carbon emissions. Basically, a race against the clock has begun, as the first significant climate targets are to be met in 2030, aiming to reduce GHG emissions by $55 \%$ from 1990 level. Several recent studies have sought to deepen the potential of hydrogen in achieving these climate goals explaining how it can be embedded into the European Union economy. It highlighted some important features and applications of hydrogen as a substitute for other polluting resources used today in energy production, transportation, or other economic and social domains. Using a regression model, the author identified a close correlation between the increase in the price of carbon certificates and the decline in coal production. An accelerated, three-fold increase in the price of carbon certificates could enable hydrogen to be used in the power sector, while ensuring post-2030 continuity for domestic natural gas production. The combination between blue hydrogen and natural gas might be the solution to eliminate two thirds of carbon emissions from energy production, while attracting European funds, as investments for the energy transition.
\end{abstract}

Keywords: Revealed competitive advantages, blue hydrogen, clean energy, decarbonization, carbon emissions.

\section{Introduction}

The European Commission has launched in the second half of 2020 two new strategic programs in order to achieve the EU`s climate ambitions as mentioned in the Green Deal framework. According to these documents, offshore wind energy and hydrogen production will become essential for the Member States essential lanes in the path to decarbonization.

The new approaches are in line with the new revised targets that were proposed by the European Commission and backed by the European Council for reducing greenhouse gas emissions (GHG) by 2030, namely an increase from $40 \%$ to 55\%, taking 1990 as the reference year. In order to achieve these ambitious objectives, decision makers need to activate updated funding mechanisms to unlock new low-carbon energy investments during 2021-2027. The allocations are based on the Taxonomy, a classification system which lists the sustainable projects that can help to reduce the greenhouse gas (GHG) emissions.

These very demanding goals embedded in the European Commission's green economic narrative were shaped during 2020, a year the EU member countries were deeply confronted with the coronavirus pandemic. The economic aftermath of the lockdowns and a deeply influenced economic environment by the pandemic convinced the European decision makers to link the postpandemic growth recovery with more ambitious climate targets. Basically, investments based on EU funding during 2021-2027 will have, from now on, ,green strings” attached.

DOI: $10.2478 /$ picbe-2021-0038

(C) 2021 V. Epurescu, published by Sciendo.

This work is licensed under the Creative Commons Attribution 4.0 License. 
At a glance, the EU model of a successful energy transition is based on the endowment with natural resources and other factors, innovation, cutting the red tape and an improved access to modern and flexible financing sources. The pace in which the polluting resources are replaced by others less GHG intensive is measured not only by reducing these values, but also through the lens of economic benefits and attracting investment.

In this respect, the author of this article started from the hypothesis that Romania is relatively well placed in terms of endowments with resources, infrastructure, and other factors to integrate itself in the hydrogen economy, transforming this energy transition into a competitive advantage, especially in the power production. Using hydrogen will enable the phase out of coal production.

The author considered the following analytical hypothesis: Black Sea has appraised natural gas reserves estimated at 200 billion cubic meters $(\mathrm{bcm})$ and the current annual natural gas production of Romania reaches yearly around $10 \mathrm{bcm}$; the European Commission has identified the Black Sea on the route of areas with considerable potential for offshore wind energy; the European Commission supports the production of hydrogen using green energy and pays attention to the production of hydrogen using natural gas as alternatives to the polluting solutions used today in power production, transportation, and industry.

Having in mind these hypotheses, the author proposed the following objectives in this paper: to identify, using the Porter model, the competitive advantages of Romania that can be used to build the hydrogen economy; to identify, using a regression method, the influence of carbon certificates on national lignite and natural gas production in order to see when lignite-based power production becomes uncompetitive; starting from these hypothesis and using international estimates, the author identified the levelized cost of energy (LCOE) of local lignite production in 2019, how it is influenced by the price of carbon certificates and compared it with the estimates made by PWC regarding the LCOE of hydrogen.

Further research is needed to truly identify the estimated costs of the transition to hydrogen in the various sectors of the economy.

\section{Literature review WHY hydrogen?}

Hydrogen begins to take the center stage in the new configuration of the European energy sector. Until now, hydrogen has failed to establish itself as a mainstream resource in the energy sector, being mainly used by the refineries, in the hydrocracking process and by fertilizers. Otherwise, in transportation and in other industrial sectors, hydrogen has a limited role and must overcome many challenges due to high technological costs and due to its chemical and physical characteristics: it is highly combustible, colorless, odorless and much lighter than methane gas.

However, hydrogen is a very versatile asset, and it can be used as a fuel, energy carrier and feedstock. With currently available technologies, hydrogen can produce, move, transfer and utilize energy in different ways. These technologies may enable hydrogen to produce fuels using renewables, nuclear, natural gas, coal or crude oil. Hydrogen can be moved by pipes or by ships if it is liquefied, being in some circumstances a valuable solution to be used for electricity (International Energy Agency, 2019).

The first efforts at the European level having in mind to establish a central role for hydrogen materialized in 2008, in the form of the HyWays project, amid rising oil prices and after Russian gas flows were interrupted due to the price disputes between the Russian Federation and Ukraine. From the technocratic point of view (European Commission. Directorate-General for Research, 
2008), hydrogen incorporation into the energy system might reshape the fundamentals of the European energy policy, hydrogen offering the possibility of lowering the carbon emissions, which foster environmental sustainability. In addition, hydrogen may be more versatile in economy by relying on a variety of primary sources of energy to ensure that supply choices continue to be secure.

In particular, hydrogen might benefit from a higher offtake of renewable sources. In the context of new challenges EU is confronted with, to cover the future clean energy needs large scale methane reforming facilities with carbon capture and storage - blue hydrogen - and electrolyzers - green hydrogen - must be deployed at a large scale. These technologies would enable hydrogen to be used as an energy carrier in the power production and as a fuel in the transportation.

According to ACEA (2020, p. 7), in 2019, there were just 137 hydrogen filling stations available across only $12 \mathrm{EU}$ countries, $16 \mathrm{EU}$ member states did not have a single hydrogen filling station and the market share of the FCEV`s was $0.04 \%$. This example demonstrates one of many challenges that hydrogen as a valuable energetic resource must overcome. Today, low carbon and green hydrogen are limited just to fresh out of the lab applications.

Some authors (Undertaking, Fuel Cells and Hydrogen 2 Joint, 2019) empirically proved that hydrogen could provide in 2030, according on two scenarios, between $4 \%$ and $6 \%$ and between to $8 \%$ and $24 \%$ in 2050 of the total EU energy demand, having applications in numerous strategic sectors. In power generation, hydrogen might provide spare capacity in order to ensure the right balancing between supply and demand. In road transportation, fuel cells electric vehicles for long distances might replace the conventional diesel and gasoline ones, while in rail transportation, old diesel trains might be replaced with engines based on hydrogen fuel cells. In heating, in the first stage, natural gas might be decarbonized by blending it with hydrogen and in a second stage, hydrogen might flow through an un upgraded gas grid. The role of hydrogen as feedstock would be ramped up, either by obtaining it from water or from methane steam reforming with CCS.

IRENA (2019, p. 7) indicates that the lowest cost of producing hydrogen from renewables and fossil fuels today is by using methane steam reforming and carbon capture and storage, while the most expensive solution is using electrolysis powered with solar energy.

The International Energy Agency (2019, p. 16) found four near-term prospects in order to enhance the widespread use of hydrogen and the nerve centers for scaling up the use of clean hydrogen are rendered by industrial ports. The refineries which are positioned near coastal areas might be incentivized to switch to cleaner hydrogen production. The success of the LNG industry might be replicated, and the international trade of hydrogen might be boosted by ramping up the industrial ports.

In July 2020, the European Commission (2020, p. 7) published a comprehensive position paper in order to highlight that hydrogen is one of the key solutions that might have a decisive contribution to enable achieving a more ambitious target in reducing GHG emissions in 2030 and decarbonize the EU economy by 2050. In fact, it is a roadmap for scaling up hydrogen production, based on three phases: between 2020-204, the strategic objective is to install at least $6 \mathrm{GW}$ of renewable hydrogen electrolysers in the EU, during 2025-2030 the strategic objective to install at least $40 \mathrm{GW}$ of renewable hydrogen electrolysers. In a post-2030 landscape, synthetic hydrogen and hydrogen-based carbon-neutral will be used on a broader scale in many economic sectors from air and transport to heavy industry and the building sector.

Hydrogen is seen as a versatile energy carrier that can contribute to both economic recovery and strengthening energy security, while reducing the GHG emissions. In addition, 37\% of the recovery package is destined to finance green projects and blue hydrogen is eligible for finance if 
the average carbon intensity of the electricity produced that is used for hydrogen manufacturing is at or below $100 \mathrm{gCO}_{2} \mathrm{e} / \mathrm{kWh}$ (European Commission, 2020).

\section{Harnessing the potential of hydrogen in Romania}

Based on the data provided by the Member States in the National Energy and Climate Plans submitted last year to the European Commission, Trinomics (2020) modeled two scenarios and assessed the fact that hydrogen demand, in Romania, would reach 1-2TWh/annum, obtained with a combined capacity of electrolysis and methane reform with carbon capture, with a capacity between 0.3 and $0.8 \mathrm{GW}$.

Some Romanian experts (Bălan, Covatariu and Dudău, 2020) consider that one path towards decarbonization and direct electrification is the development of offshore wind farms that might enable the production of hydrogen at a large scale. However, a compelling green hydrogen case depends on the evolution of the EUTS $\mathrm{CO}_{2}$ prices and on a mature deployed technology with higher capacities for the wind farms.

One of the most specific challenges, in this case, is finding the right balance between low cost and high-quality wind and solar energy for electrolyzers with high production capacities and a low levelized cost of energy (IRENA, 2019).

In the short run, natural gas production becomes the big enabler of the energy transition, by switching coal in the power sector and converting to hydrogen to generate clean power, especially due to the fact that the pandemic accelerated the switch from coal to gas. This was seen in Europe and North America, due to unusually low natural gas prices that accelerated the phase out of several coal-fired power plants (IEA, 2020).

While the biggest potential for hydrogen is seen in the refinery sector and in transportation, the quickest wins might be achieved in the power sector, with the phase out of coal production.

According to an activity report of the National Energy Regulatory Agency (2018, p. 25), Romanian coal fired power plants generate $911,14 \mathrm{gr}$ of $\mathrm{CO}_{2} / \mathrm{KWH}$ while gas fired plants generate only 407,04 gr of $\mathrm{CO}_{2} / \mathrm{KWH}$. Phasing out lignite faster from the national power production will contribute to reducing carbon emissions by two-thirds in the national power mix.

Coal might be substituted, depending on cost efficiency leviers, either with natural gas, either by blending natural gas-hydrogen or directly with hydrogen. This will depend on the future policies of the European Commission regarding the ETS prices. It should be highlighted that once the fourth trading phase of the EU Emissions Trading System got started, EU carbon prices recorded an all-time high, of EUR 34.25 per ton of $\mathrm{CO}_{2}$. (Watson and Bowles, 2021) However, the European Commission states that carbon prices in the range of EUR 55-90 per ton of $\mathrm{CO}_{2}$ would be needed to make fossil-based hydrogen with carbon capture competitive with fossil-based hydrogen today (European Commission, 2020).

According to the PRIMES scenario made in 2016 (Ministerul Economiei, Energiei și Mediului de Afaceri, 2020), the estimated carbon price will reach EUR $50 \mathrm{tCO}_{2} / \mathrm{kwh}$ in 2040 . One might say, at an empirical level, that the projections need an update because we might see much earlier this level of taxation. Based on this sketchy projection, the Ministry of Energy estimates that coal will have in 2030 a $1900 \mathrm{MW}$ of total installed power. However, hydrogen, according to Trinomics (2020, p. 30), might have a potential of 800 MW installed power, in Romania. If hydrogen will have priority for dispatching, as do other green energy sources, coal will be phased out much earlier than expected.

Dudău and Iuga (2018, p. 49) stated that given the sufficient availability of natural gas, the conversion of methane to hydrogen has the potential to ensure very large reductions in carbon 
emissions - provided the capture and storage (CCS) - possibly also the use - of carbon resulting from the production of methane hydrogen.

As carbon taxation grows, coal production becomes uncompetitive leaving room for the modern, alternative solutions, such as hydrogen, that will have to be deployed at large scale on a short term. This demonstrates that the energy transition is policy dependent.

However, the high costs of hydrogen production from offshore wind energy and the technological challenges (availability, power transportation from offshore to onshore, storage capacities, etc.) might make enough room for blue hydrogen in a shorter term.

There is another key motivating factor by replacing coal with hydrogen. Methane reform could trigger a potential for carbon to be reused to other useful, high-value products. Some of the applicable approaches are conversion into polycarbonate fuels, chemicals, and plastics. Carbon may turn into a feedstock with multiple uses in the fertilizer production, storage of $\mathrm{CO}_{2}$ in solid materials with economic value or using it in enhanced processes of mature oil and gas fields.

Romania could, in this way, build two value chains: one based on the capitalization of carbon as feedstock and one around hydrogen, with a triple use: feedstock for refineries and metallurgical industry, energy carrier for power production and fuel for road and rail transportation.

\section{Methodology}

In this paper, the author opted for a mainly phenomenological analysis and, with the help of the positivist dimension, sought to capture the most representative and useful causal relationships relevant for the analyzed phenomena. In this paper, a multi-parameter analysis, the author appeals to the Porter's Diamond model in order to identify the main pillars of a potential hydrogen economy in Romania. Using a regression model, the author pointed out the relevant connection between carbon prices and lignite and natural gas production to identify the level of resilience of the fossil power production against the rising levels of the $\mathrm{CO}$ taxation. To illustrate them, the author made references to literature and used statistical databases published by ACEA, Eurostat, IRENA, NAER and IEA.

Identifying this correlation, the author demonstrated the impact of a price of 55 euro / $\mathrm{CO}_{2} \mathrm{t}$ and 90 euro / $\mathrm{CO}_{2} \mathrm{t}$ on coal-based electricity production. This impact, measured on the basis of the price benchmark indicated by the European Commission, demonstrates the turning point at which hydrogen could become a solution for electricity production.

\section{Results and discussions}

Opting for the Porter Diamond model to identify the main pillars that could contribute to the creation of a hydrogen economy in Romania, the author followed to underline that these potential scale advantages can be categorized according to firm strategy, structure and rivalries, factor conditions, demand conditions and related and supportive industries.

Firm Strategy, Structure and Rivalries:

- Existing strong competition in retail and non-retail fuel market; significant competition on the power market (both upstream and downstream) with an important network of filling stations; oligopolistic competition in upstream natural gas production; however, Black Sea Oil \& Gas will be the third gas producer if will start the offshore gas production;

- Existing refineries that produces hydrogen as a feedstock for the hydrocracking process, for obtaining fuels - Rompetrol announced a strategy in order to produce in the future green hydrogen; in present, it produces hydrogen without CCS; 
- Factor conditions;

- EU policies towards clean energy production and towards decarbonizing transportation and heavy industry;

- Specialized workforce; two hydrogen research institutes, in Pitesti and Râmnicu Vâlcea;

- Offshore wind potential estimated at $22 \mathrm{GW}$ and potential appraised and discovered natural gas reserves in offshore Black Sea estimated at $200 \mathrm{bcm}$;

- Gas infrastructure and geological formations (salt caverns, oil and gas depleted deposits) that, with technical developments, might be transformed into hydrogen storages;

- Demand conditions;

- Significant number of power consumers estimated at over 8.7 million and over 3 million natural gas consumers; over 7 million registered vehicles;

- Related and supported industries;

- Strong value chains in automotive industry; Dacia has a research institute for the hydrogen engine;

- Strong value chains in the fuels, power and natural gas production and distribution;

- Heavy industries that uses hydrogen (refining) or might use hydrogen (steel, cement, fertilizer) as feedstock;

- Four important shipyards (Constanța, Galați, Brăila, Mangalia) where the infrastructure for transporting hydrogen by water can be built.

The author also used time series to illustrate the evolution of the annual production of coal (lignite) and natural gas and the yearly average evolution of the prices of carbon certificates for the period 2014-2019.

Table 1. Romanian yearly lignite and natural gas production and avg annual carbon price, between 2014 - 2019

\begin{tabular}{|r|r|r|r|}
\hline \multicolumn{1}{|c|}{ Year } & \multicolumn{1}{c|}{$\begin{array}{c}\text { Coal / Lignite } \\
\text { (thousand tons) }\end{array}$} & $\begin{array}{c}\text { Natural gas } \\
\text { (million cubic meters) }\end{array}$ & $\begin{array}{c}\text { Avg carbon price } \\
\text { (EUR) }\end{array}$ \\
\hline $\mathbf{2 0 1 4}$ & 25425 & 11056 & 6.04 \\
\hline $\mathbf{2 0 1 5}$ & 26426 & 11092 & 7.72 \\
\hline $\mathbf{2 0 1 6}$ & 23245 & 9811 & 5.31 \\
\hline $\mathbf{2 0 1 7}$ & 26212 & 10582 & 5.92 \\
\hline $\mathbf{2 0 1 8}$ & 24539 & 10278 & 16.40 \\
\hline $\mathbf{2 0 1 9}$ & 22034 & 9959 & 24.60 \\
\hline
\end{tabular}

Source: Combined data from INSSE and Investig.com for lignite production and natural gas and for yearly avg carbon price https://www.investing.com/commodities/carbon-emissions-historical-data.

Based on these time series, the author applied a regression model to identify the impact of the change in the price of carbon certificates on national lignite and natural gas production and at what price for carbon emissions would be hydrogen competitive. If carbon emissions had not been taxed, then the average annual lignite production might have been 26,281 thousand tons. At an increase by one monetary unit of the price of emissions, lignite production decreases by 148 thousand tons compared with 2019 levels, with the R square indicator of the regression model being 0.45. If the carbon prices would have increase from EUR 24.6 to EUR 55 in 2020, then lignite production would have registered a steep decline by 18,119 thousand tons, namely a $17.74 \%$ decrease compared with the one recorded in 2019. If the carbon price would have increased to EUR 90 , then, the lignite production would have declined to 12.925 thousand tons, namely a $41.44 \%$ yoy decrease. This decrease would have a similar impact in the lignite power output. 
In 2019, the lignite production generated a $1581 \mathrm{MWh}$ of power. If carbon prices would have reached EUR 90 in 2020, a 41.44\% decrease would have meant that power generated with coal would have decreased to $926 \mathrm{MWh}$, similar, with the actual realized output in 2020, namely 1073 MWh.

One explanation could be that natural gas in power generation was much more competitive in terms of price than coal, and this trend persisted during the whole year, amid a flat average national consumption, around 6621MWh, compared with previous years.

The regression model shows that natural gas is more resilient than coal in terms of influence of the carbon price, with a $\mathrm{R}$ square indicator of 0.2 .

If carbon emissions had not been taxed, then the annual gas production would have been at $10.8 \mathrm{bcm}$ in 2020. A carbon price of EUR 55 would have triggered a decline of the Romanian gas production to $9,073.29 \mathrm{bcm}$, ie $0.88 \mathrm{bcm}$ yoy decrease of natural gas. A carbon price of EUR 90 might had triggered a decline in the annual gas production to $7,967.58 \mathrm{bcm}$, ie a $1.9 \mathrm{bcm}$ decrease yoy.

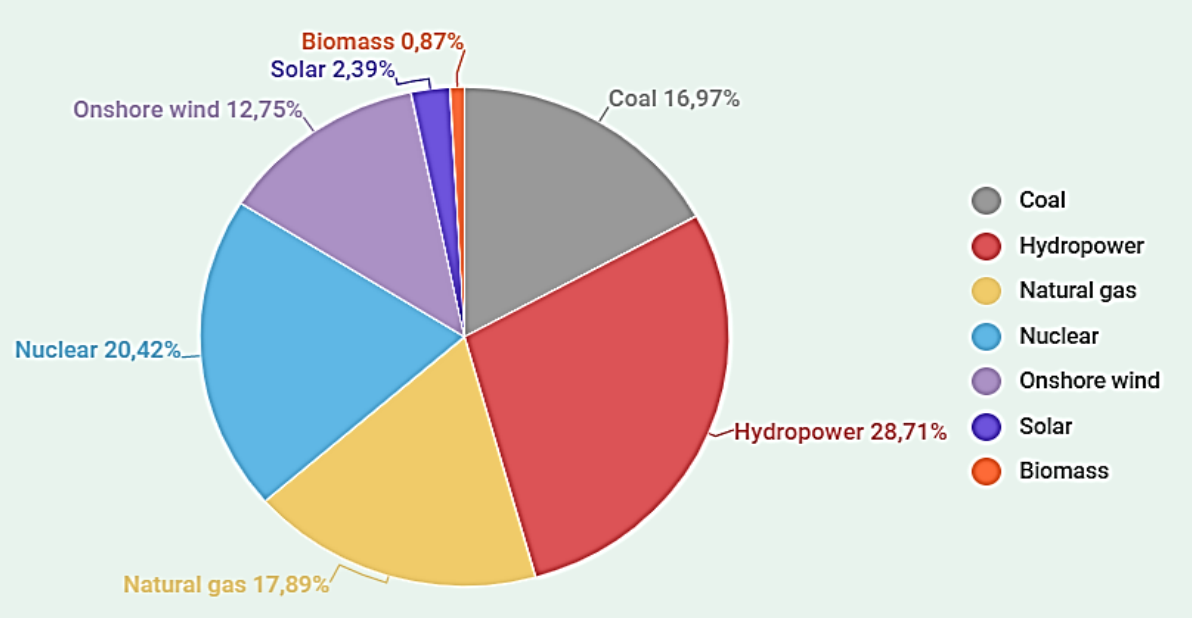

Figure 1. Romanian power production by energy carrier in $\mathbf{2 0 2 0}$

Source: Data processed by the author from sistemulenergetic.ro/.

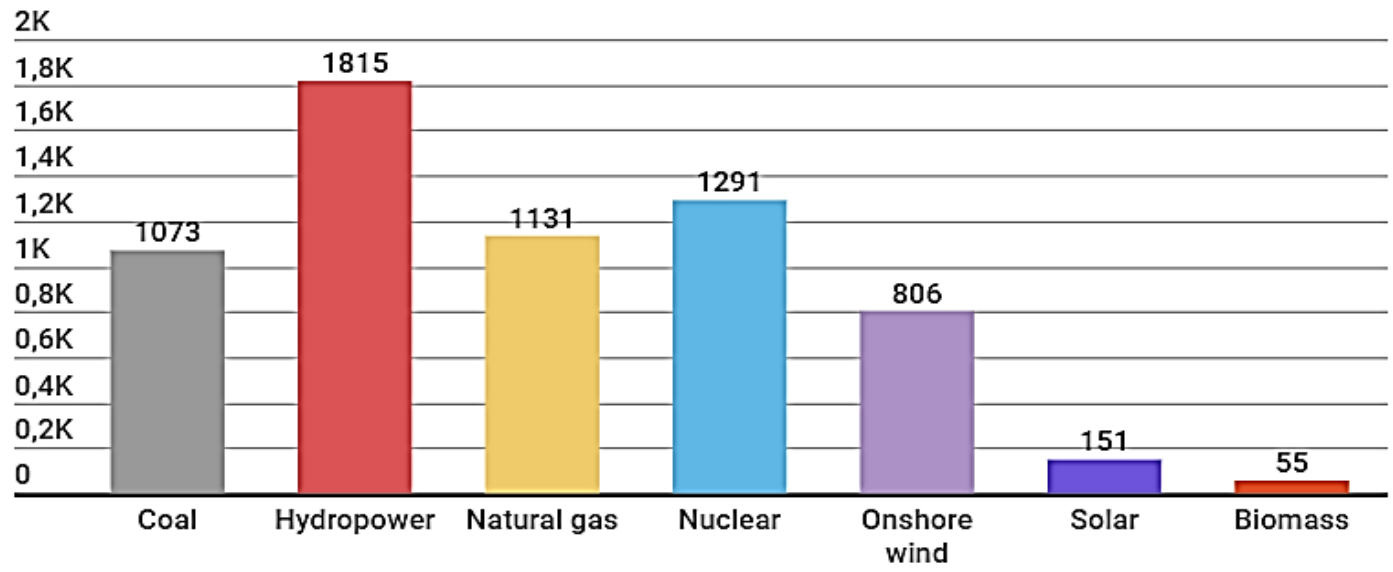

Figure 2. Romanian power production by energy carrier in $\mathbf{2 0 2 0}$

Source: Data processed by the author from sistemulenergetic.ro/. 
Based on international benchmarks, out of 1.9 cubic meters of natural gas it might be obtained 0.6 kilogram of hydrogen with $100 \%$ efficiency during the process. (H2 Tools) Under ambient conditions, out of one cubic meter of hydrogen might be obtained $3 \mathrm{kWh}$ of energy content. (Hy Web) The ambient conditions in order to obtain hydrogen during methane steam reforming are the following: a temperature of $850^{\circ} \mathrm{C}$, a water-gas shift in order to recover with syngas the volumes of hydrogen and a metal catalyst plus a membrane catalytic membrane to ensure a high quality equilibrium during this processes (Chen, 2010).

Based on Trinomics benchmark, the level of efficiency in obtaining hydrogen out of natural gas is around 60\%. However, there are other benchmarks found by the author: 67\% (Shareqet al., 2019), 74\% (Encyclopedia of Sustainable Technologies, p. 9) or between 60\% and 80\%. (Brun et al., 2019).

At $60 \%$ efficiency, that means that out of $1.9 \mathrm{bcm}$ of natural gas it might be obtained, through methane steam reforming, around 1.05TWH of hydrogen, enough to cover the Romanian potential demand in power production by replacing coal, giving a steady consumption level yoy.

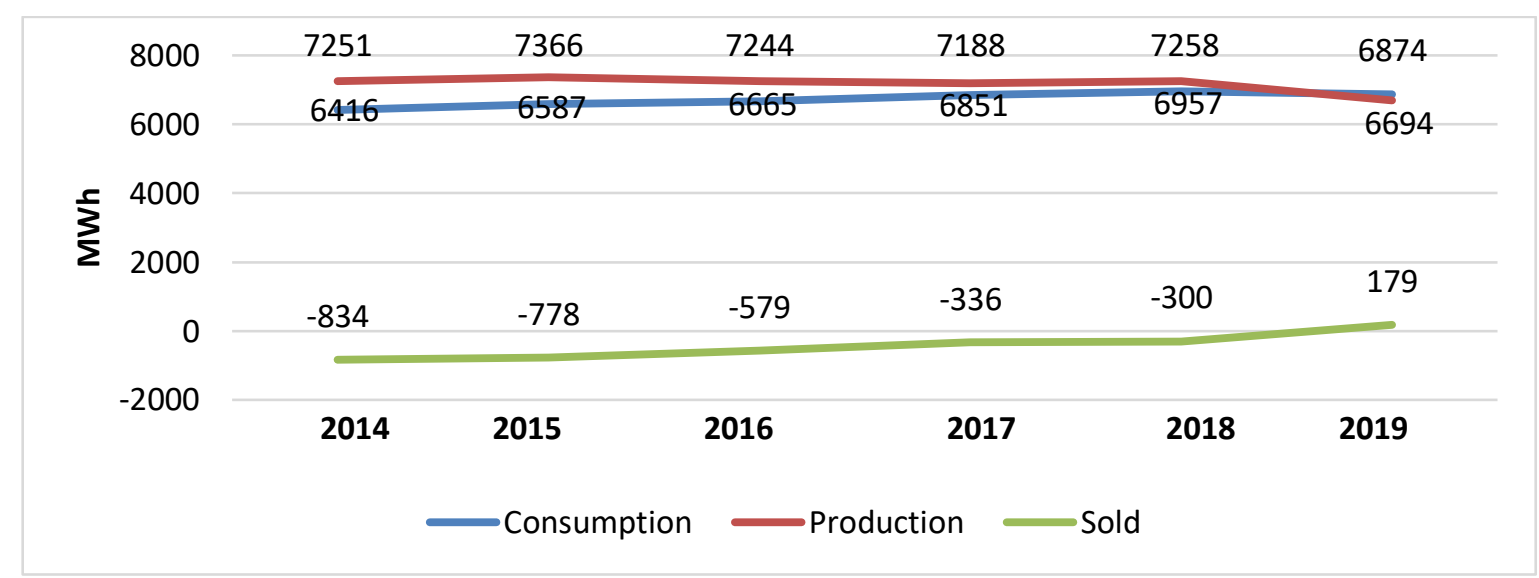

Figure 3. Consumption, production and imports versus exports during 2014-2019

Source: Data processed by the author from sistemulenergetic.ro/.

Other two elements that indicate the need to accelerate the evaluation of the possibilities to introduce blue hydrogen in the electricity production mix is given by the financial situation of the Complexul Energetic Oltenia, the national producer of lignite-based electricity and the looming uncertainty regarding the chances that the company has to obtain European funds to diversify its electricity production.

It may be highlighted that, at the end of 2019, the Romanian Government adopted a memorandum on granting a loan in the form of a rescue aid for CE Oltenia, to be able to pay the carbon certificates for 2019. The amount of the rescue aid was 1,200,000,000 lei. The aid was granted in the following terms: either CE Oltenia repays this loan within 6 months or will present a Restructuring Program, by notifying the European Commission. The Ministry of Economy proposed a restructuring plan which is now being investigated by the European Commission, under the doubts that the plan, if implemented, will not ensure the viability of the company without any other state support scheme. Given that the average price for 2019 of carbon certificates was EUR 26.60/ton of $\mathrm{CO}_{2}$, another possible budgetary effort, if the price of carbon certificates would reach EUR 50 in the short term, would be 2,255,000,000 lei and, if the price reaches EUR 90, the 
budgetary effort could be 4,060,150,000 lei. In this case, CE Oltenia should reimburse these amounts from its own funds.

\section{Conclusion}

Without considering this paper to be an attempt to establish a business model for hydrogen, the author considered the capture of the most sensitive causal relationships, the highlighting of which may allow a better substantiation of the process of reporting on energy challenges. The identification of Romania's strengths within Porter's model for developing a hydrogen economy was made at the empirical level. The regression model used only considers the internal production of natural gas and lignite. Otherwise, it must be deepened if it can be used in other countries that depend on fossil fuels for electricity production.

However, this paper tries to demonstrate a strong correlation between the evolution of the carbon taxation and the national production of lignite and natural gas. The regression method proposed by the author could help determine when the national lignite production will no longer be able to survive on the market even by subsidizing the carbon certificates. A three-fold and a half times increase in the price of carbon certificates would mean a budgetary effort of approximately 4 billion lei per annum and which, in any case, would not contribute to the objective of reducing carbon emissions.

At first glance, the gap left by the lignite production in the electricity production mix due to the increase of the carbon taxation could be taken up in the first stage by hydrogen produced from natural gas. However, a thorough study is needed to identify the impact of investments in new technologies in the price of electricity. Hydrogen could be competitive only if the price of electricity produced will be at least equal to that produced by lignite.

Empirical estimates made in this paper based on LCOE show that hydrogen has the potential to become more competitive than lignite, but it depends on the evolution of carbon certificate prices and European funds available for projects that use hydrogen production technologies.

Building a value chain of carbon by using it in other applications (e.g. obtaining plastics) could significantly contribute to reducing the cost of producing hydrogen from natural gas. Increasing the efficiency of the conversion process from natural gas to hydrogen through technological improvements will also be able to help reduce costs in the future.

The use of blue hydrogen in electricity production could also contribute to the reduction of carbon emissions but could also contribute to the fact that Romania could become a net exporter of electricity without emissions. Hydrogen in the electricity generation sector will be able to lead to the creation of new industries both horizontally and vertically that could prepare the ground for green hydrogen. In addition, it would prevent a significant part of the national gas transmission system from becoming a stranded asset. In addition, the natural gas reserves discovered in the Black Sea could be a significant resource for blue hydrogen. In the long run, the potential of the Black Sea wind energy could transform this region of Romania into a large industrial cluster concentrated around the production of clean power.

\section{References}

Autoritatea Naţională de Reglementare în Domeniul Energiei (2018). Raport anual privind activitatea Autorităţii Naţionale de Reglementare în Domeniul Energiei, 25.

Balan, M., Covatariu, A., \& Dudau, R. (2020). Romania`s Offshore Wind Energy Resources, 3. 
Bruni, G., Rizzello, C., Santucci, A., Alique, D., Incelli, M., Tosti, S. (2019) On the energy efficiency of hydrogen production processes via steam reforming using membrane reactors, International Journal of Hydrogen Energy, 998.

Chen, I.-T. (2010). Steam Reforming of Methane. Retrieved from http://large.stanford.edu/ courses/2010/ph240/chen1/.

Dudau, R., \& Iuga, V. (2018). Perspectivele gazelor naturale în România și modalități de valorifcare superioară a acestora, 49.

Encyclopedia of Sustainable Technologies (2017) Methane Steam Reforming. Retrieved from: https://www.sciencedirect.com/topics/engineering/methane-steam-reforming/pdf.

European Automobile Manufacturers Association (2020). Making the transition to zero-emission mobility, 7.

European Comission (2020). A hydrogen strategy for a climate-neutral Europe. Retrieved from https://eur-lex.europa.eu/legal-content/EN/TXT/?uri=CELEX:52020DC0301.

European Comission. Directorate-General for Research (2008). HyWays. The European Hydrogen Roadmap, 7.

European Commission (2020). A hydrogen strategy for a climate-neutral Europe, 7.

European Commission (2020). Taxxonomy. Techinical Report. Retrieved from https://ec.europa .eu/info/sites/info/files/business_economy_euro/banking_and_finance/documents/190618 -sustainable-finance-teg-report-taxonomy_en.pdf .

$\mathrm{H} 2$ Tools (n.d.). ENERGY EQUIVALENCY OF FUELS (LHV). Retrieved from h2tools.org: https://h2tools.org/hyarc/hydrogen-data/energy-equivalency-fuels-lhv.

Hy Web. (n.d.). Hydrogen data - hydrogen data. Retrieved from http://www.h2data.de/: http://www.h2data.de/.

IEA (2020). Energy Outlook 2020, 70.

International Energy Agency (2019). The Future of Hydrogen. Seizing today's opportunities, 13. IRENA (2019). Hydrogen: A renewable energy perspective, 27.

Ministerul Economiei, Energiei și Mediului de Afaceri (2020). The 2021-2030 Integrated National Energy and Climate Plan, 67, 148.

Shareq N. M., Jan H. C., Schalk C., Shahriar A. (2019). Efficient hydrogen production with $\mathrm{CO}_{2}$ capture using gas switching reforming, 1 .

Trinomics (2020). Opportunities arising from the inclusion of Hydrogen Energy Technologies in the National Energy and Climate Plans, iii.

Undertaking, Fuel Cells and Hydrogen 2 Joint (2019). Hydrogen Roadmap Europe. Luxemburg: Publications Office of the European Union, 5-8.

Watson, F., \& Bowles, A. (2021, January 4). EU carbon prices hit all-time high of Eur34.25/mt as phase four starts. Retrieved from https://www.spglobal.com/: https://www.spglobal .com/platts/en/market-insights/latest-news/coal/010421-eu-carbon-prices-hit-all-time-high -of-eur3425mt-as-phase-four-starts.

Yahya, A., Raed, K., Ramzi, H., \& Shihab, E. (2020). The dawn of green hydrogen. Maintaining the GCC's edge in a decarbonized world. PWC. Retrieved from https://www.strategyand .pwc.com/m1/en/reports/2020/the-dawn-of-green-hydrogen/the-dawn-of-green-hydrogen .pdf. 